\title{
Entrepreneurial orientation and new venture performance in emerging markets: the mediating role of opportunity recognition
}

\author{
Muhammad Anwar $^{1}$ (D) Thomas Clauss ${ }^{1}$ (D) $\cdot$ Wunnam Basit Issah $^{1}$
}

Received: 26 March 2020 / Accepted: 25 February 2021 / Published online: 24 March 2021

(c) The Author(s) 2021

\begin{abstract}
How entrepreneurial orientation facilitates the identification of new opportunities in newly established ventures in emerging economies remains largely unexplored. Approaching entrepreneurial orientation as a second order latent construct, we examined the mediating role of opportunity recognition on new venture performance. Using a survey data from 316 SMEs, the results of the analysis in SmartPLS highlights that entrepreneurial orientation indirectly contributes to the performance of new ventures, where the relationship is partially mediated by opportunity recognition. The findings show that firms with high entrepreneurial orientation can identify and exploit new opportunities as well as enjoy superior performance.
\end{abstract}

Keywords Entrepreneurial orientation - Opportunity recognition · New venture performance $\cdot$ Sensing capacity

Jel Classification L26 $\cdot$ M13 · M16

Thomas Clauss

thomas.clauss@uni-wh.de

Muhammad Anwar

muhammad.anwar@uni-wh.de

Wunnam Basit Issah

wunnam.issah@uni-wh.de

1 WIFU-Endowed Chair for Corporate Entrepreneurship and Digitalization in Family Business, Witten Institute for Family Business, Witten/Herdecke University, Alfred-Herrhausen-Straße 50, 58455 Witten, Germany 


\section{Introduction}

Many emerging economies are confronted with immense challenges such as uncertain markets (Czakon et al. 2020; Yu et al. 2020), globalization (Fatima 2017), new market systems (Alvarez et al. 2015) and intense competition (Chari and Banalieva 2015). As compared to developed markets, new ventures suffer from a higher failure ratio due to institutional challenges. For instance, Wang and Chen (2010) argue that in China, more than $70 \%$ of newly established ventures fail in the first year. Another study by Parnell et al. (2015) reports $67 \%$ failure ratio of Chinese ventures in the first year while $85 \%$ in the first 10 years. Anwar and Ali Shah (2020) report that more than $50 \%$ of new ventures in Pakistan do not survive in the long run. These institutional challenges impinge on the growth of small and medium enterprises (SMEs) largely due to the liability of newness and smallness, which limits their ability to adapt rapidly to changing business conditions (Yu et al. 2020). Consequently, the ability of these firms to exploit new opportunities in order to survive the competition is impeded (Zhou and Li 2010; Chen et al. 2020). Thus, bringing to the fore the issue of performance and survival of newly established SMEs in emerging economies (Anwar and Ali Shah 2020; Yu et al. 2020; Guo et al. 2019a).

The issue of performance, profitability and competitive advantage of new ventures have extensively been addressed by prior studies, for the example through the lenses of the resource-based view (RBV) and organization theory (See Filser et al. 2014; Hughes et al. 2015). However, the explanations provided by these prior studies may be incomplete when they are applied to the specific context of newly born ventures in emerging economies. Reasons include poor entrepreneurial capabilities, lack of resources and poor competencies, which hinder the growth and survival of new ventures (Anwar and Ali Shah 2020; Yu et al. 2020). More precisely, ventures in developed economies do not have the magnitude of resource constraints as faced by ventures in emerging economies. It is important to note that small ventures have fewer resources for opportunity recognition as compared to large firms (Wright and Etemad 2001) and, thus, less leverage and higher risks when doing business in a dynamic environment (Yuliansyah et al. 2016). Moreover, the institutional setting, competition and digital trends in developed and advanced markets are different from emerging markets (Schneider 2018; Devece et al. 2019). Therefore, firms in emerging markets often search for less expensive and less risky but fruitful alternatives for growth.

However, very little is known about the factors that facilitate the recognition of new opportunities and success in newly established ventures. It has been shown that not all enterprises can recognize an opportunity and transform it into a successful undertaking (Wasdani and Mathew 2014). Meanwhile, with time some ventures develop better capabilities to recognize, exploit new opportunities and succeed in turbulent markets (Gielnik et al. 2012; Tang et al. 2012). There is a growing research interest in these capabilities of opportunity recognition (Filser et al. 2020). However, how entrepreneurial orientation (EO), innovativeness, risk-taking and proactiveness facilitate the recognition of new opportunities that in turn enhance the performance of new ventures particularly in emerging markets has not yet been fully established. 
To fill this important gap in the literature, we used an untested path to explore if EO directly or indirectly contributes to new venture performance through opportunity recognition.

There are two main reasons for testing the hypothesized model in the context of newly born SMEs in emerging economies. First, as mentioned earlier that little is known about the role of EO in opportunity recognition that results in the success of new ventures. There is ample evidence of the benefits of EO in new and matured ventures in both emerging and developed economies (Marom et al. 2019; Jin et al. 2017; Parida et al. 2016; Yang and Meyer 2019). Research also highlights the advantages of opportunity recognition for enterprises (Guo et al. 2019b; Gielnik et al. 2012; Hamel 2012; Hansen et al. 2011). However, there is little evidence that demonstrates how a newly established venture creates and exploits an opportunity (e.g., Cai et al. 2016; Nambisan and Zahra 2016; Vogel 2017). Additionally, the following questions remain unexplored: (a) What is the effect of EO on opportunity recognition in new ventures in emerging economies (b) How does opportunity recognition mediate the relationship between and new venture performance in emerging economies?" Second, ventures in emerging economies continue to outgrow those in developed economies (Prashantham et al. 2019). For instance, the growth of new product development (Jin et al. 2019), internationalization process (Anwar et al. 2018) and investments by venture capitalists (Wu and Xu 2020) are reported more in emerging economies than in developed markets. Surprisingly, the rate of failure of newly born ventures is higher in emerging economies in comparison to those in advanced economies (Anwar and Shah 2020). The failure can be attributed to a lack of capabilities, insufficient resources, poor entrepreneurial skills and opportunities. Therefore, the decision to test the model in emerging markets allows us to assess if EO enables the discovery of opportunities and long-term survival of new ventures.

We provide important contributions to the study of EO and new venture growth. First, we extend the literature on EO and venture growth to the specific context of emerging markets. The context is particularly important as it reveals an important but less explored dimension in EO studies. Therefore, we show how different venture growth could turn out for firms in emerging economies. Second, considering the extra-ordinary failure ratio of new ventures in emerging markets, our research provides worthy insights on the mitigating failure of new ventures. That is how EO (as an intangible and convenient source) enables new enterprises to the recognition of useful opportunities in order to avoid failure. Third, we use empirical data of 316 new ventures from an emerging market (Pakistan) and employed EO as a first and second-order construct (post hoc analysis) in partial least squares (PLS) for opportunity recognition and new venture performance. It allows us to advance the existing literature of EO by taking us one-step ahead of previous studies that used EO as the first-order construct in simple regression analysis. Fourth, the inconclusive and mixed evidence investigated by previous studies (e.g. positive, significant and insignificant etc.), allow researchers to examine potential mechanisms between EO and performance. We hereby assess a possible mechanism (opportunity recognition) (Lumpkin and Dess 1996) that can be an actual mediator in the apparent empirical disjunction. Fifth, we add a 
contribution of an empirical value to earlier extensions of RBV by showing the performance gains obtained from using EO as a resource. For instance, EO is deemed as an intangible resource, which facilitates firms in acquiring sustainable positions in the market (Anwar and Shah 2020).

The rest of the paper is organized as follows: Sect. 2 discusses the theoretical background and hypothesis development. The methodology is presented in Sect. 3 while the results are presented in Sect. 4. Finally, we present the discussion and conclusion in Sect. 5.

\section{Theoretical background and hypothesis development}

\subsection{Opportunity recognition}

"One of the pillars of entrepreneurship research is the concept of 'opportunity" (Harms et al. 2009). Opportunity recognition demonstrates the capability of a firm to identify a good idea and transform it into a business impression that improves value and creates revenues (Lumpkin and Lichtenstein 2005). Opportunity recognition focuses on market and customer demands as well as helps in problem-solving to make firms successful (Shrader and Hills 2015). It also contributes to a firm's performance (Cassia and Minola 2012). Meanwhile, identifying and exploiting opportunities is still poorly understood (Nambisan and Zahra 2016; Vogel 2017; Wang et al. 2013).

For the last 3 decades, opportunity recognition has become a key topic in the field of entrepreneurship (Donbesuur et al. 2020; George et al. 2016; Yang and Meyer 2019). However, there is little agreement on the accepted definition of opportunity recognition (Hulbert et al. 2015). For instance, Bull and Willard (1993) demonstrated that "entrepreneurship" appears under conditions of: first, a task-related motivation (certain visions or social values that motivate individuals to act); second, available expertise (knowledge about the current situation); third, a personal gain expectation (e.g., economic and psychological benefits and goals); and, fourth, a supportive environment. According to the authors, these conditions impact the ability of an individual (e.g., entrepreneur) who searches for an opportunity and aims to benefit from the opportunity. For instance, Kirzner (1985) demonstrated that an entrepreneur is one who perceives profit opportunities and undertakes actions to fill the presently unsatisfied need or process inefficiencies.

Opportunity recognition is based on experiences and entrepreneurial characteristics (Parida et al. 2016) and entrepreneurial behavior that follows (Wasdani and Mathew 2014). Firms with strong potential towards opportunity recognition are more successful over those having little opportunity recognition in the market (Ketchen et al. 2007). There is a great chance of failure if SMEs cannot search or identify opportunities in a dynamic market (Sambasivan et al. 2009). Considering the high ratio of failure of new ventures in emerging markets, recognition of new opportunities is deemed a key strategy of success (Zhou and Li 2010; Chen et al. 2020). Apparently, small firms are more flexible and adapt to changes more quickly than large firms. For this reason, they may have a higher degree of EO (Rauch et al. 
2009) but a lack of resources forces them to rely on new opportunities (Ireland et al. 2003; March and Simon 1968).

\subsection{Entrepreneurial orientation}

While there is no precise definition of EO (Lechner and Gudmundsson 2014), a three-dimensional model is used to describe EO. Its elements include innovativeness, risk-taking, and proactiveness (Covin and Slevin 1989). Although Lumpkin and Dess (1996) propose two additional dimensions-competitive aggressiveness and autonomy-most authors support the three-dimensional model (Shirokova et al. 2016; Su et al. 2011; Wiklund 1999; Zahra and Garvis 2000).

A closer look at the three dimensions reveals a construct that may be directly or indirectly related to a firm's performance. First, innovativeness is about supporting and inspiring new ideas as well as investigation and creativity (Lumpkin and Dess 1996). Second, risk-taking tells us about "the degree to which owners and managers of firms are willing to take the risk and make great resource commitments" (Miller and Friesen 1978, p. 923). Finally, proactiveness means searching for novel opportunities which may or may not be complementary to the existing line of operations (Lumpkin and Dess 1996).

There are two schools of thought regarding the influence of EO on a firm's performance. The first group of authors claims that EO does not always directly influence performance but rather some internal factors and capabilities, which mediate its relationship to a firm's performance. Examples include networking (Jiang et al. 2017), market orientation (Amin et al. 2016), competitive strategy (Lechner and Gudmundsson 2014), or strategic entrepreneurship (Kantur 2016). By contrast, the other group of authors argues that EO has a significant direct influence on performance (e.g., Chen and Yang 2009; Kraus et al. 2012; Zahra et al. 2001). In line with our previous arguments, we align with the first school of thought and assume an indirect influence of EO on a firm's performance. Indeed, several studies have revealed that newly established ventures persistently seek opportunity recognition to ensure their survival in the market (De Carolis and Saparito 2006; Gielnik et al. 2012). If opportunity recognition requires EO and entrepreneurial alertness (De Carolis and Saparito 2006; Khodaei et al. 2016; Wiklund and Shepherd 2005), we can assume a mediated (indirect) effect of EO on a firm's performance.

Entrepreneurship theory also supports the notion that since opportunities are heterogeneous, the features of the opportunity may either empower or restrain the founder's distinctive information, which can influence a new firm's performance (Dencker and Gruber 2015). This logic can be transferred to the three dimensions of EO. Innovative firms can benefit from new opportunities (Day 2011; Lin and Wu 2014), if firms try to respond to external changes proactively, i.e. respond to external change-new opportunities-before competitors can respond. Proactiveness helps them to exploit the new opportunity ahead of competitors (Day 2014; Kozlenkova et al. 2014). Moreover, a firm must be a risk-taker to seize the benefits of new opportunities and attain high profitability (Zahra et al. 2001). 


\subsection{Hypothesis development}

\subsubsection{Entrepreneurial orientation and new venture performance}

EO is a significant strategic factor for new ventures due to its key role in firm growth, success and financial performance (Donbesuur et al. 2020). It was originally conceptualized in three dimensions namely innovativeness, risk taking and proactiveness (Miller and Friesen 1978). However, two additional dimensions were later added. These new dimensions include competitive aggressiveness and autonomy (e.g., Lumpkin and Dess 1996). All these features are considered vital for new business success (Jin et al. 2017; Parida et al. 2016; Yang and Meyer 2019). While, most studies in the context of emerging markets, have highlighted the first three dimensions of EO for competitive advantage and business success (Ma et al. 2017; Su et al. 2011; Zhao et al. 2011).

Innovativeness is a crucial factor for a firm's performance. The innovative capability allows firms to innovate, which in turn, helps them develop competitive advantages and gain positive outcomes (Cooper 2000). Firms should emphasize both product innovation and firm innovation to sustain their position in emerging markets (Story et al. 2015). Guo et al. (2019a) shed light on building new and unique products and revealed that new ventures in emerging economies such as China need high innovative qualities to ensure their success. In such regions, innovative strategy is important for new ventures to meet the needs of operational activities (Singh and Gaur 2018). Anwar (2018) also demonstrated that an innovative business model is a substantial factor of competitive advantage and SMEs performance in Pakistani SMEs. Emerging markets are considered as volatile, turbulent and uncertain (Alam et al. 2019). Innovativeness is a strategic resource with which a firm deals with fluctuations in its internal life and external environment. In order to respond to a turbulent environment, it is vital to invest in innovativeness to be able to realize a competitive advantage and achieve high performance (Hult et al. 2004). In turbulent markets, innovativeness helps SMEs to enhance their performance and survive (Kraus et al. 2012; Rhee et al. 2010).

However, innovativeness alone might not be enough. Entry into a new market, new brand recognition, and new product development also require a highrisk-taking behavior (Brettel et al. 2015; Zahra et al. 2001). Empirical evidence indicates that CEOs with higher levels of risk propensity create higher value for their firms (Danso et al. 2016; Lumpkin and Dess 1996; Ferris et al. 2017). Furthermore, the risk-taking propensity is especially vital for owners and managers of SMEs who are competing in emerging markets because risk-taking activities enhance superior financial performance in such markets (Danso et al. 2016). Consequently, risk-taking is not only a part of the $\mathrm{EO}$ construct but also a requirement for entrepreneurs if they want to achieve a high degree of performance.

Finally, proactive firms gain benefits from early market entry and can thus acquire a competitive advantage, higher returns and profitability, and attain a stronger brand recognition than their main competitors (Wiklund and Shepherd 2005). In emerging markets such as China, new ventures use proactive approaches to scan the environment for potential activities that benefit them (Gao et al. 
2018). Furthermore, discovering new opportunities is very crucial for newly born ventures in emerging economies. Proactiveness enables enterprises in exploiting new opportunities that result in satisfactory performance (Yang and Meyer 2019). Highly proactive ventures tend to achieve higher market returns and enjoy success in the industry by introducing new products and services before their competitors (Jalali et al. 2014). Overall, EO is very crucial for new process and value creation (Wales et al. 2020). In view of this we predict a positive association between high EO and firm performance.

Hypothesis 1 New ventures in emerging markets with high entrepreneurial orientation will have high performance.

\subsubsection{Entrepreneurial orientation and opportunity recognition}

In this study, we argue that EO allows not only for high performance but also for better opportunity recognition by new ventures. In fact, the empirical study of Wang and colleagues (2013) indicates that entrepreneurial efficacy and skills have a significant influence on opportunity recognition. To discover a new opportunity, new ventures need proactive, innovative and risky behaviors (Parida et al. 2016). A firm can exploit growth opportunities via innovation in the context of product development and process (Geroski 1990). Innovativeness helps firms to seize new opportunities through novel approaches or by offering new products in the present market (Berry et al. 2010). Empirical evidence indicates that there is a significant positive association between innovative new ventures and opportunity recognition in emerging economies (Chen and Yang 2009).

There is a broad agreement that quantifiable risk is also associated with opportunity recognition (Maine et al. 2015). Risk perception, for example, is one of the most crucial aspects in opportunity evaluation among firms (Dali and Harbi 2016). Risk-taking firms make high investments when pursuing opportunities, particularly if the environment is benevolent and opportunities are large (Stevenson and Jarillo 1990). Firms with a risk-taking propensity commence even more risky projects and show boldness when executing proactive strategies to exploit opportunities (Stevenson and Jarillo 1990). Risk-taking is shown to be associated strictly with opportunity recognition and exploitation (Runyan et al. 2008).

Related to risk-taking, proactiveness is an opportunity-seeking, forward-looking perspective characterized by the introduction of new products and services ahead of the competition and acting in anticipation of future demand (Rauch et al. 2009). To achieve success in a market, entrepreneurs must proactively search for information, e.g., new opportunities, about their competitors, customers, and market conditions (Galbraith 1973). In highly competitive markets, proactiveness assists entrepreneurs in forward-looking orientation and opportunity-seeking that drive them ahead of major competitors (Covin and Wales 2012). New ventures should be proactive, so they will actively engage in new projects and services, discovering new opportunities and new product development (Ghosh et al. 2001). New ventures in emerging markets get advantages of the proactive alliance to discover new opportunities easily (Yang and Meyer 2019). For instance, in emerging economies such as China, SMEs 
cannot survive and succeed in the market, if they are unable to proactively search and identify new opportunities (Guo et al. 2017). The ability to identify opportunities depends on the readiness and alertness to environmental changes (Stevenson and Gumpert 1985). It has been shown that proactive behavior on the part of SMEs has a significant direct influence on opportunities (Ojiako et al. 2015). Thus, we hypothesize a positive effect of EO on opportunity recognition capabilities.

Hypothesis 2 New ventures in emerging markets with high entrepreneurial orientation will have high capabilities of recognizing new opportunities.

\subsubsection{Opportunity recognition and new venture performance}

It has been shown that opportunity recognition a substantial predictor of SMEs' performance, success and growth in emerging economies (Guo et al. 2017). Due to resource constraints and poor support, the majority of SMEs in emerging economies look for favorable opportunities that present a low level of risks and costs (Guo et al. 2019b). Due to fast changes in market demands, customer preferences, and the strong competition in markets, firms increasingly rely on novel opportunities in order to survive and achieve success (Hamel 2012; Hansen et al. 2011). Ventures that can identify the presence and value of an opportunity can act upon them and profit (Shane and Venkataraman 2000). Such opportunities provide several benefits, including sustainable performance (Ojiako et al. 2015).

In SMEs, where owners and managers play a greater role, this is even more pronounced, since management characteristics influence OR, which in turn influences a firm's performance (Sambasivan et al. 2009). A higher degree of motivation among employees towards opportunity recognition might make them willing to participate in entrepreneurial activities. These activities are related to a higher frequency of opportunities recognized (Urban and Wood 2015). OR, in turn, significantly contributes to a new venture's competitive advantage and high performance (Gielnik et al. 2012; Guo et al. 2017). For instance, it has been shown that a firm's ability to recognize new opportunities can significantly increase performance (Sambasivan et al. 2009; Wasdani and Mathew 2014). Because of the foregoing discussion we predict that opportunity recognition capabilities will have a positive association with firm performance.

Hypothesis 3 Emerging market firms with high capabilities of opportunity recognition will have high performance.

\subsubsection{Indirect effects of entrepreneurial orientation}

We hypothesize about the influence of EO on a new venture's performance and on opportunity recognition. As a mediation mechanism, we also hypothesize about the influence of opportunity recognition on new venture performance. In fact, opportunity recognition is the explanatory variable that sheds light on why 


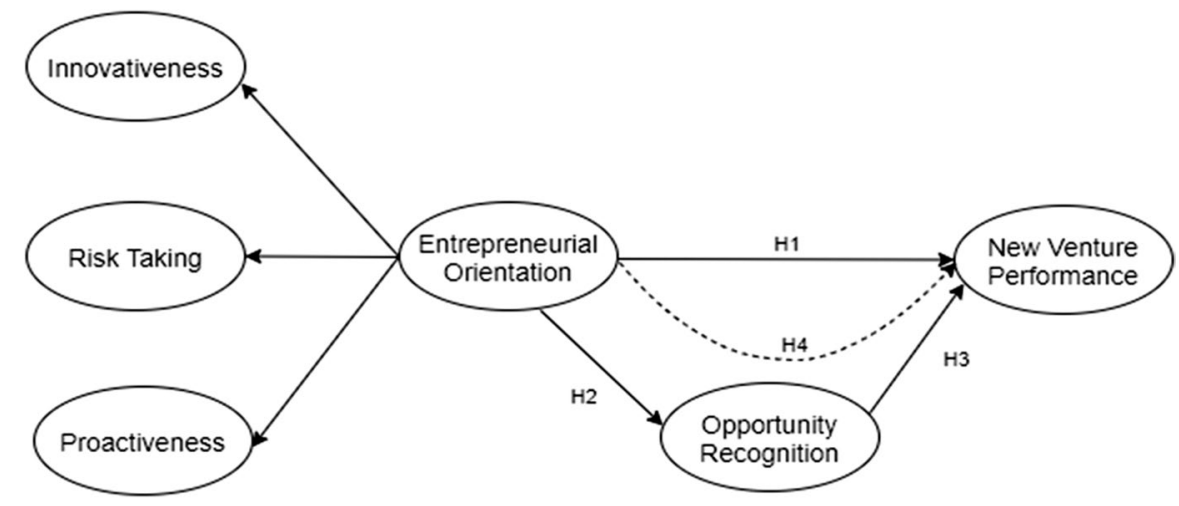

Fig. 1 Theoretical model

EO increases a new venture's performance. Prior studies have suggested several mediating mechanisms between EO and firm performance such as acquisitive learning (Gupta et al. 2020), financial performance (Kallmuenzer et al. 2018), competitive strategies (Lechner and Gudmundsson 2014), observed capacity (Khodaei et al. 2016) etc. Moreover, Adomako et al. (2018) identify EO as an important predictor of new venture success through increased use of networking capabilities. Similarly, Wang et al. (2017) also indicated that newly born ventures sustain their performance through EO but they also need support mechanisms to be competitive in the market. Furthermore, Donbesuur et al. (2020) demonstrate that EO assists the performance of new ventures through entrepreneurial actions (an act of searching and exploiting new opportunities). In emerging markets, top managers/owners of SMEs use their intangible skills and capabilities to build new products and develop new ideas that in turn contribute to the sustainable competitive position (Ali et al. 2020).

Nambisan and Zahra (2016) argue that the recognition of an opportunity strongly relies on entrepreneurial abilities. Indeed, recent studies in this field have shown that firms with high EO and with high alertness can recognize new opportunities in the market (Lumpkin and Dess 2001; Renko et al. 2012; Su et al. 2011; Tang et al. 2012). Nevertheless, there might be other explanatory variables. For instance, a manager's decision-making characteristics could influence OR, which in turn affects the success and growth of the firm (Davidsson 2015). Similarly, when firms perceive greater opportunities for technological progress, they tend to put more effort into R\&D investment and innovation (Nieto and Quevedo 2005). EO enable new ventures in entrepreneurial activities such as developing new ideas, developing new markets, searching for opportunities, managing resources and new way of doing things needed for growth and survival of new ventures (Cardon et al. 2013; Yitshaki and Kropp 2016). A recent empirical study about Taiwanese ventures reveals that entrepreneurial features assist new ventures in perceived and actual opportunity recognition that in turn influence 
performance (Chen et al. 2020). Therefore, we expect a partial mediation and hypothesize that:

Hypothesis 4 The impact of entrepreneurial orientation on new venture performance in an emerging market is mediated by the ability of a firm to recognize new opportunities.

Figure 1 presents the theoretical framework of our study.

\section{Methodology}

\subsection{Sample}

The research hypotheses were tested on empirical data collected from SMEs operating in Pakistan. We considered Pakistan to be an interesting place to collect data because it is an emerging market with structural market problems that requires a high degree of entrepreneurship (Hyder and Lussier 2016). Data were collected in the joint cities; Islamabad (capital of Pakistan) and Rawalpindi (the industrial center). Firms were obtained from the Rawalpindi Chamber of Commerce and Industry (5408 firms) and the Islamabad Chamber of Commerce and Industry (3751 firms). We focused on owners and managers since they can identify new opportunities with the help of market information and motivational intention (Hulbert et al. 2015). Moreover, owners and managers are more concerned and responsible for the strategic planning and performance of firms (Anwar 2018).

In this study, the paper and pencil questionnaire was sent to the selected firms. We wrote a cover letter, stressing the anonymity of the data collection and asking participants to answer alone without the help of their colleagues. We asked them to give the first answer which came to their mind and reminded them that there were no right or wrong answers, in order to avoid socially desirable answers. Before sending our questionnaire, we pretested it with academic peers. The average time of filling the questionnaire was $9 \mathrm{~min}$. All questions were in English, which is one of the official languages in Pakistan, and since all participants were managers or business owners with a relatively high level of education, we could assume that language would not be an issue.

Excluding micro firms, we contacted firms with 20-250 employees and asked the owners and managers to fill out the questionnaire. In addition, we focused only on those firms that can be considered as new ventures, meaning those that started their operation in the last 10 years. We sent out questionnaires to 700 newly established ventures and 358 responses attained a response rate of $51 \%$. However, some of the questionnaires were filled incorrectly or did not fulfill the criteria of the study, resulting in 316 usable questionnaires. Details of participant owners/managers are presented in Table 1 . In our research, we focused on three business fields: manufacturing, trading, and services. Overall, 118 manufacturing 
Table 1 Sample characteristics

\begin{tabular}{|c|c|c|}
\hline Description & Frequency & Percentage \\
\hline \multicolumn{3}{|l|}{ Owners/managers } \\
\hline 1. Owner & 74 & 23.4 \\
\hline 2. Manager & 238 & 75.3 \\
\hline 3. Missed & 4 & 1.30 \\
\hline \multicolumn{3}{|c|}{ Education of owners/managers } \\
\hline 1. Bachelor and below & 74 & 23.4 \\
\hline 2. Master & 226 & 71.5 \\
\hline 3. Post-doctoral & 14 & 4.4 \\
\hline 4. Missed & 2 & 0.60 \\
\hline \multicolumn{3}{|l|}{ Experiences of business } \\
\hline 1. 5 years and less & 101 & 32.0 \\
\hline 2. 6-10 years & 72 & 22.8 \\
\hline 3. $11-15$ years & 66 & 20.9 \\
\hline 4. $16-20$ years & 36 & 11.4 \\
\hline 5. 21 and above years & 39 & 12.3 \\
\hline 6. Missed & 2 & 0.60 \\
\hline \multicolumn{3}{|l|}{ Firm age } \\
\hline 1. 3 years and less & 72 & 22.8 \\
\hline 2. 4-7 years & 148 & 46.8 \\
\hline 3. $8-10$ years & 91 & 28.8 \\
\hline 4. Missed & 5 & 1.60 \\
\hline \multicolumn{3}{|l|}{ Size of firms } \\
\hline 1. 20-50 employees & 90 & 28.5 \\
\hline 2. 51-100 employees & 141 & 44.6 \\
\hline 3. 101-250 employees & 83 & 26.3 \\
\hline 4. Missed & 2 & 0.60 \\
\hline \multicolumn{3}{|l|}{ Nature of industry } \\
\hline 1. Manufacturing & 118 & 37.3 \\
\hline 2. Trading & 119 & 37.7 \\
\hline 3. Services & 74 & 23.4 \\
\hline 4. Missed & 5 & 1.60 \\
\hline $\mathrm{N}=$ & 316 & 100 \\
\hline
\end{tabular}

firms, 119 trading firms, and 74 service firms participated in our survey, with 5 participants who did not indicate the field of their firm's activity. Ninety small firms (20-50 employees), 151 small to medium-sized firms (51-100 employees), and 83 medium-sized firms (101-250 employees) completed our questionnaire, with 2 participants who did not indicate their firm's size. The age of the firms also varied: 72 firms were 3 years or younger, 148 firms were active for $4-7$ years, 91 firms had been in the market for 8-10 years. Five participants did not indicate 
their firm's age. 238 participants held managerial positions in their firms and 74 participants indicated that they own the firm, with 4 participants not indicating their position. In our data collection, we also obtained a good coverage of participants working experience-101 participants had less than 5 years of working experience, 72 participants worked for more than 6 but less than 10 years, 66 worked for 11-15 years, 36 worked for 16 to 20 years, and 39 participants had worked for more than 21 years.

\subsection{Measures}

\subsubsection{Independent variables}

In our research, we focused on three independent variables-innovativeness, risktaking, and proactive behavior. These variables were aggregated into a reflectivereflective second-order construct. Each of these variables was measured with three items which can be found in Table 1. Our study relied on measures used in prior studies (Covin and Slevin 1989; Shirokova et al. 2016) using a 5-point Likert scale, ranging from "strongly disagree" to "strongly agree".

\subsubsection{Dependent and mediating variables}

Our main dependent variable — a new venture's performance-was measured using a 5-point Likert scale ranging from "extremely declined" to "extremely improved". We used 6 items (adopted from Anwar 2018), which had a very good Cronbach's $\alpha$ and showed a very high composite reliability (see Table 4).

The opportunity recognition measure was adopted from the study by Guo et al. (2016). The items can be found in the "Appendix". Meanwhile, the validity and reliability statistics are presented in Table 4.

\subsubsection{Control variables}

We controlled for the firm size and firm age effects, as well as industry effects, which is in line with what Shirokova and colleagues (2016) suggest for SMEs.

\subsection{Empirical method}

We utilized SmartPLS 3.0 (Ringle et al. 2015) to test our model structure. Recently, studies showed that PLS is an established and robust state-of-the-art method for studies in business (Carrión et al. 2016) and strategic management research (Hair et al. 2014).

We use the path weighting scheme. To obtain the standard errors for our structural model testing, we used nonparametric bootstrapping with 2000 replications and mean replacement of missing values. The type 1 reflective-reflective 
Table 2 Correlations coefficients

\begin{tabular}{lrrrlllllll}
\hline Variables & Mean & Kurtosis & Skewness & 1 & 2 & 3 & 4 & 5 & 6 & 7 \\
\hline 1. Firm age & 2.0611 & -1.074 & -0.092 & - & & & & & & \\
2. Firm size & 1.9777 & -1.183 & 0.036 & -0.064 & - & & & & & \\
3. Innovativeness & 3.8054 & 1.115 & -0.493 & -0.103 & -0.068 & - & & & & \\
4. OR & 3.7903 & -0.650 & -0.650 & -0.023 & -0.025 & 0.394 & - & & & \\
5. Proactiveness & 3.8038 & 1.997 & -0.520 & -0.019 & -0.023 & 0.327 & 0.424 & - & & \\
6. Risk taking & 3.6804 & 1.740 & -0.719 & -0.046 & -0.024 & 0.145 & 0.459 & 0.267 & - \\
7. NVP & 3.7981 & 1.431 & -0.394 & 0.022 & -0.057 & 0.390 & 0.568 & 0.413 & 0.316 & - \\
\hline
\end{tabular}

$O R$ opportunity recognition, $N V P$ new venture performance

Table 3 Items and factor loadings

\begin{tabular}{|c|c|c|c|c|c|}
\hline Cross loadings & Innovativeness & Risk-taking & Proactiveness & $\begin{array}{l}\text { Opportunity } \\
\text { recognition }\end{array}$ & $\begin{array}{l}\text { Venture } \\
\text { perfor- } \\
\text { mance }\end{array}$ \\
\hline inn 1 & 0.855 & 0.154 & 0.291 & 0.351 & 0.367 \\
\hline inn 2 & 0.904 & 0.144 & 0.291 & 0.381 & 0.373 \\
\hline inn3 & 0.868 & 0.081 & 0.275 & 0.300 & 0.281 \\
\hline $\mathrm{rt} 1$ & 0.146 & 0.874 & 0.274 & 0.416 & 0.355 \\
\hline $\mathrm{rt} 2$ & 0.140 & 0.838 & 0.209 & 0.347 & 0.195 \\
\hline $\mathrm{rt} 3$ & 0.059 & 0.742 & 0.160 & 0.365 & 0.213 \\
\hline pro1 & 0.273 & 0.231 & 0.892 & 0.398 & 0.381 \\
\hline pro2 & 0.193 & 0.231 & 0.725 & 0.276 & 0.266 \\
\hline pro3 & 0.342 & 0.215 & 0.888 & 0.383 & 0.381 \\
\hline or1 & 0.336 & 0.388 & 0.331 & 0.787 & 0.410 \\
\hline or2 & 0.229 & 0.292 & 0.339 & 0.676 & 0.397 \\
\hline or3 & 0.312 & 0.341 & 0.278 & 0.712 & 0.404 \\
\hline or 4 & 0.260 & 0.356 & 0.291 & 0.712 & 0.394 \\
\hline or 5 & 0.334 & 0.348 & 0.356 & 0.858 & 0.519 \\
\hline nvp1 & 0.327 & 0.295 & 0.374 & 0.484 & 0.868 \\
\hline nvp2 & 0.232 & 0.186 & 0.336 & 0.335 & 0.741 \\
\hline nvp3 & 0.331 & 0.270 & 0.336 & 0.510 & 0.799 \\
\hline nvp4 & 0.337 & 0.284 & 0.353 & 0.463 & 0.867 \\
\hline nvp5 & 0.383 & 0.222 & 0.319 & 0.508 & 0.764 \\
\hline nvp6 & 0.259 & 0.267 & 0.289 & 0.429 & 0.818 \\
\hline
\end{tabular}

higher-order construct for EO was specified using the repeated indicator method (Ringle et al. 2012). 
Table 4 Reliability and validity statistics

\begin{tabular}{llllll}
\hline Reliability and validity & MSV & Cronbach's alpha & $\begin{array}{l}\text { Composite } \\
\text { reliability }\end{array}$ & AVE & $\begin{array}{l}\text { Discri- } \\
\text { minant } \\
\text { validity }\end{array}$ \\
\hline Innovativeness & 0.198 & 0.848 & 0.908 & 0.767 & 0.876 \\
Risk taking & 0.250 & 0.756 & 0.860 & 0.672 & 0.820 \\
Proactiveness & 0.205 & 0.785 & 0.876 & 0.703 & 0.839 \\
Opportunity recognition & 0.299 & 0.805 & 0.866 & 0.565 & 0.752 \\
Venture performance & 0.299 & 0.895 & 0.920 & 0.658 & 0.811 \\
\hline
\end{tabular}

Table 5 Heterotrait-Monotrait ratio of correlations (HTMT)

\begin{tabular}{|c|c|c|c|c|c|c|c|c|}
\hline Factors & $\mathrm{EO}$ & Firm age & Firm size & Innovative & OR & Proactiveness & Risk taking & NVP \\
\hline \multicolumn{9}{|l|}{$\mathrm{EO}$} \\
\hline Firm age & 0.098 & & & & & & & \\
\hline Firm size & 0.068 & 0.064 & & & & & & \\
\hline Innovativeness & 0.875 & 0.112 & 0.073 & & & & & \\
\hline OR & 0.765 & 0.077 & 0.067 & 0.473 & & & & \\
\hline Proactiveness & 0.863 & 0.031 & 0.032 & 0.394 & 0.531 & & & \\
\hline Risk taking & 0.855 & 0.055 & 0.033 & 0.174 & 0.590 & 0.342 & & \\
\hline NVP & 0.629 & 0.030 & 0.063 & 0.440 & 0.660 & 0.489 & 0.374 & \\
\hline
\end{tabular}

$E O$ entrepreneurial orientation, $O R$ opportunity recognition, $N V P$ new venture performance

\subsection{Measurement assessment}

Our data show an acceptable approximation to the normal distribution of the constructs as mean values the main constructs range between 3.6804 and 3.8054 and skewness and kurtosis measures were below I2I (George 2011). Table 2 shows the descriptive statistics and inter-construct correlations of the used variables.

To ensure the quality of our measures, we assessed the psychometric properties of our reflective measures in SmartPLS relying on commonly agreed indicators for reliability and validity (Hair et al. 2011). We assessed indicator reliability by calculating the standardized factor loadings of all reflective items (Table 3).

We further assessed t Cronbach's $\alpha$ and composite reliability, finding consistent support for the internal consistency of our constructs. Convergent validity was substantiated since all constructs exceeded an average variance explained (AVE) of 0.5 (Fornell and Bookstein 1982). Since all AVE values exceeded the highest squared inter-construct correlations, discriminant validity according to the Fornell-Larcker criterion was confirmed. Additionally, we calculated the heterotrait-monotrait ratio (HTMT), which is a new criterion for testing discriminant validity. A value lower than 0.90 indicates that the discriminant validity has been established (Franke and Sarstedt 2019). In our research, we have achieved the goal as all the constructs have desirable HTMT values. The results of our measurement model assessment are summarized in Tables 4 and 5 . 
Table 6 Variance inflation factor/multicollinearity

\begin{tabular}{lll}
\hline Factors & $\begin{array}{l}\text { Opportunity rec- } \\
\text { ognition }\end{array}$ & $\begin{array}{l}\text { Venture } \\
\text { perfor- } \\
\text { mance }\end{array}$ \\
\hline Entrepreneurial orientation & 1.010 & 1.567 \\
Firm age & 1.011 & 1.012 \\
Firm size & 1.008 & 1.008 \\
Opportunity recognition & & 1.553 \\
\hline
\end{tabular}

\subsection{Common method bias}

To test whether there was a common method bias since all data were collected using a paper and pencil questionnaire, we first performed Harman's single factor test (Podsakoff and Organ 1986). The test revealed that all reflective items put into one factor explained $37.36 \%$ of the variance. This test showed that the common method should not be an issue. Nevertheless, Harman's single factor test provides no statistical control for method effects, hence we used a marker variable approach to test the potential bias. A marker variable is defined as "a variable that is theoretically unrelated to the substantive variable and for which is expected correlations with this substantive variable is zero" (Williams et al. 2010, p. 478). Lindell and Whitney (2001) were the first researchers who demonstrated the concept of marker variable in a cross-sectional data set by describing that the marker variable should be theoretically unrelated to at least one focal variable. We used the previous business experience of the owners/managers as a marker variable that was used in the survey. Five options were given that show (1) 5 years and below experience, (2) 6-10 years, (3) 11-15 years, (4) 15-20 years and (5) 21 and above years of experience. We compared the zero-order correlations of our focal constructs to the results of a partial correlation in which the marker variable was partialled out (Lindell and Whitney (2001). After adding the marker variable, all the correlations values among the focus variables were significant. Moreover, the highest difference between the adjusted correlations and zero-order construct was very low-confirming the absence of common method bias.

\section{Results}

Our structural model assessment showed that the model could explain a substantial degree of the variance of endogenous constructs. We checked the multicollinearity to ensure the absence of overlapping in the constructs due to high order constructs of the EO. Multicollinearity evaluates overlapping between independent variables that are loaded over dependent variables in a model. According to Hair et al. (2010), Variance Inflation Factor (VIF) values lower than 3 ensures the absence of multicollinearity problem in results. The values of our results as presented in Table 6 


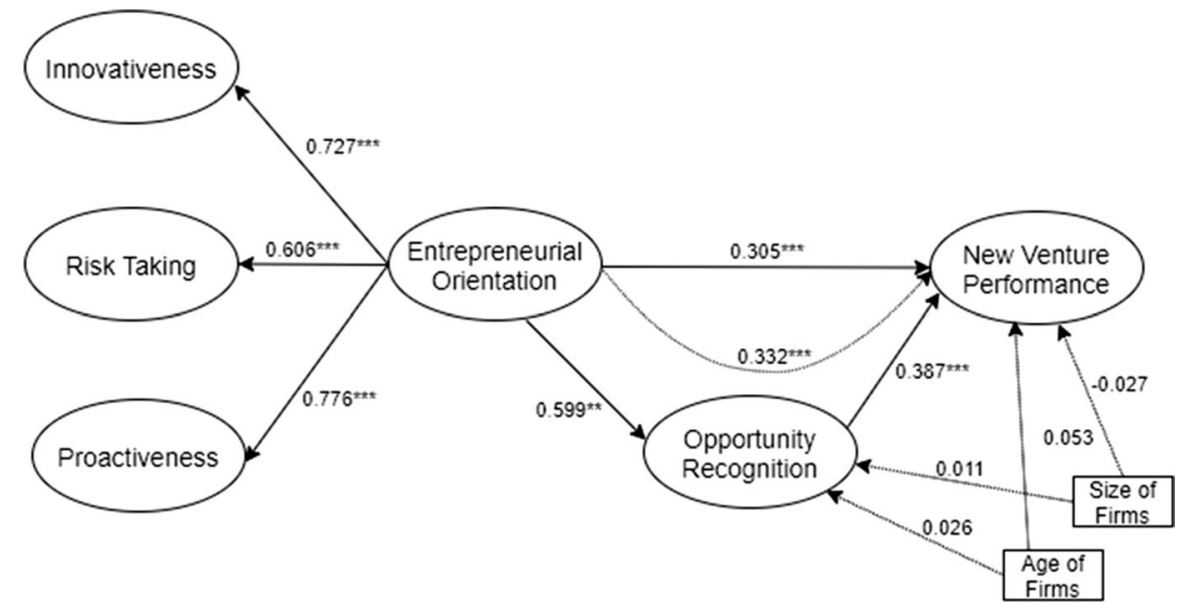

Fig. 2 Structural model

indicate that there is no overlapping among the independent variable and towards the dependent.

We calculated the effects sizes $\left(\mathrm{f}^{2}\right)$ of all tested effects in the conceptual model. It shows that EO has a small effect $\left(\mathrm{f}^{2}=0.096\right)$ while opportunity recognition has a medium effect $\left(f^{2}=0.156\right)$ on new venture performance. Moreover, EO has a large effect on opportunity recognition $\left(f^{2}=0.551\right)$ in the model. We assessed the predictive relevance of our model with the $\mathrm{Q}^{2}$ statistics calculated through an omission distance of 7. As in our results, all exogenous constructs show values greater than 0 , predictive relevance is given.

We ran the full model including the mediator with all control variables and the results are given in Fig. 2. We found EO having a significant impact on opportunity recognition $(\beta=0.599, \mathrm{t}=11.956, p=0.001)$ and on new venture performance $(\beta=0.305, \mathrm{t}=4.370, p=0.000)$. At the same time, opportunity recognition had a statistically significant impact on a new venture's performance $(\beta=0.387, t=5.453$, $p=0.000$ ). Consequently, we supported our hypotheses 1,2 , and 3 . The control variables produced no significant effects $(p>0.1)$.

The path between EO and a new venture's performance (C-path) remained significant $(\beta=0.232, \mathrm{t}=4.770, p=0.000)$. We performed a Sobel test as proposed by Lowry and Gaskin (2014). The Sobel test supported a significant mediation: $t=2.208, p=0.027$. Nevertheless, the introduction of the mediator did not make the C'-path insignificant. Based on the approach by Baron and Kenny (1986) we conclude a partial mediation. Thus, we hold our hypothesis 4 for partially supported.

$\mathrm{R}$ square illustrates that in the presence of the control variables; age and size of firms, EO explains $35.6 \%$ variance in opportunity recognition and $38.5 \%$ variance in new venture performance (through opportunity). 
Table 7 First order constructs and new venture performance

\begin{tabular}{llll}
\hline Paths & Direct effects & Indirect effects & Total effects \\
\hline Control variables effects & & & - \\
Age of firms $\rightarrow$ NVP & 0.050 & - & - \\
Size of firms $\rightarrow$ NVP & -0.021 & - & - \\
Age of firms $\rightarrow$ Opportunity recognition & 0.026 & - & - \\
Size of firms $\rightarrow$ Opportunity recognition & 0.010 & & $0.293^{* * *}$ \\
Main effects & & $0.102^{* * *}$ & $0.213^{* * *}$ \\
Innovativeness $\rightarrow$ NVP & $0.191^{* *}$ & $0.138^{* * *}$ & $0.275^{* * *}$ \\
Risk taking $\rightarrow \mathrm{NVP}$ & 0.075 & $0.093^{* *}$ & - \\
Proactiveness $\rightarrow$ NVP & $0.182^{* *}$ & - & - \\
Innovativeness $\rightarrow$ opportunity recognition & $0.267^{* * *}$ & - & - \\
Risk taking $\rightarrow$ opportunity recognition & $0.360^{* * *}$ & - & - \\
Proactiveness $\rightarrow$ opportunity recognition & $0.243^{* * *}$ & - & - \\
Opportunity recognition $\rightarrow$ NVP & $0.382^{* * *}$ & & -
\end{tabular}

$N V P$ new venture performance

${ }^{* *} p \leq 0.01, * * * p \leq 0.001$

\subsection{Post hoc analysis}

In addition to the first-order construct, we assessed the influence of the second-order constructs; innovativeness, risk-taking and proactiveness on new venture performance through the opportunity recognition as a mediator. We found little difference between the results of second-order and first-order constructs.

We found (see Table 7) that innovativeness has an indirect significant influence on new venture performance $(\beta=0.102, \mathrm{t}=4.190, p=0.000)$, and the direct impact is also significant $(\beta=0.191, \mathrm{t}=2.625, p=0.009)$. It demonstrates that opportunity recognition partially mediates the relationship between innovativeness and new venture performance. However, risk taking has a significant indirect effect $(\beta=0.138$, $\mathrm{t}=4.419, p=0.000)$, but did not show a direct significant impact on new venture performance $(\beta=0.075, \mathrm{t}=1.370, p=0.171)$. It reveals that the relationship between risk taking and new venture performance is fully mediated by opportunity recognition. Proactiveness significantly influences new venture performance directly $(\beta=0.182, \mathrm{t}=3.291, p=0.001)$ and indirectly $(\beta=0.093, \mathrm{t}=3.256, p=0.001)$. It describes that the relationship between proactiveness and new venture performance is partially affected by opportunity recognition. We further found that innovativeness, risk taking and proactiveness have a significant influence on opportunity recognition $(\beta=0.267, \mathrm{t}=7.556, p=0.000, \beta=0.360, \mathrm{t}=2.625, p=0.009$ and $\beta=0.243, \mathrm{t}=4.338, p=0.000)$ respectively. Additionally, the total effects of innovativeness, risk taking and proactiveness on new venture performance are significant $(\beta=0.293, \mathrm{t}=4.311, p=0.000, \beta=0.213, \mathrm{t}=3.673, p=0.009$ and $\beta=0.275$, $\mathrm{t}=4.575, p=0.000)$ respectively. The controlled factors; size and age of firms have no significant role in the model. 


\section{Discussion and conclusion}

\subsection{Discussion}

We examined the mediating role of opportunity recognition between EO and new venture performance in a single model within the context of an emerging market. Emerging markets provide a setting that allows us to elucidate the mediating role of EO, which is used as a first and second-order reflective construct built upon the dimensions of innovativeness, risk-taking, and proactive behavior. The empirical results support our theoretical predictions that high EO in new ventures is associated with increased opportunity recognition and new venture performance. We also found empirical support for our prediction that opportunity recognition is associated with increased performance in new ventures. This research reveals that EO spurs new venture performance in emerging markets. This is in line with Kraus and colleagues (2012), who observed that EO is an important antecedent of firm performance.

We find partial support for our prediction about the mediating effect of opportunity recognition between EO and venture performance. The observed partial mediation could mean either a missing mediator, or both a direct and an indirect impact. Interestingly, the partial mediation observed in our study does not fully match Donbesuur et al. (2020) who have shown that entrepreneurial opportunity discovery fully mediates the path between EO and new venture performance. However, our findings align with Anwar et al. (2018) who observed a partial mediating role of competitive advantage between entrepreneurial strategy and new venture performance. Also, our findings align with Soekotjo et al. (2001) who scrutinized that SMEs use EO to configure market performance, but in the meantime, EO helps them in building new products for the market. Our findings also display equal importance of EO for opportunity recognition and new venture performance in emerging markets. In other words, the findings argue that the dimensions of EO contribute to the recognition of opportunities and in the meantime help in securing performance. To summarize, our research did find the full mediating role of OR, but we suggest that the relationship between EO and new venture performance in emerging markets is partially affected by opportunity recognition. Consequently, it opens a new door for future researchers and policymakers to investigate what factors fully mediate or moderate the paths.

However, the post hoc analysis revealed little change in our results indicating a fully mediating role of opportunity recognition between risk-taking and new venture performance. While the outcome of the post hoc analysis does not invalidate our main results, the findings are in consonance with Helm et al. (2010) who demonstrate that managers/owners with high-risk propensity engaged in innovative and novel ideas to enhance the performance of their new ventures. Similarly, our findings are related to Zehir et al. (2015) who showed that risk-taking indirectly contributes to firm performance through differentiation strategy as a mediator. Our findings show that risk-taking managers/owners are persistently engaged in the recognition of new opportunities to spur their profitability. In other words, our research states 
that new ventures with risk-taking propensity significantly recognize new opportunities in the market to survive for the long run.

Our study reveals that EO is a significant predictor of opportunity recognition in new ventures (Wang et al. 2020). It is also in consonance with the notion that holds opportunity recognition as a key characteristic of an entrepreneur who shapes and exploits opportunities for profitability (Shane and Venkataraman 2000). Firms with proactive, innovative and risk-taking abilities have high potential of discovering opportunities in new markets (Patel et al. 2015). Indeed, entrepreneurial firms need innovative, proactive and risky behaviors to exploit new opportunities in a dynamic market (Alvarez and Busenitz 2001). Our research has shown that in turn, opportunity recognition significantly contributes to new venture performance in emerging markets. Our findings are in line with Miocevic and Morgan (2018) who observed that strong abilities of opportunity recognition ensure high growth and efficiency in emerging markets. Moreover, our findings align with Guo et al. (2019b) who observed that small ventures are engaged in discovering opportunities to compete in emerging markets and respond to external pressures.

\subsection{Contribution to theory and literature}

Our study provides important contributions to the literature on EO, opportunity recognition and new venture growth. First, the main contribution of this study advances our understanding of the relationship between EO, opportunity recognition and new venture growth concerning emerging economies or markets. Previous studies have explored fragmented results (weak, significant, or insignificant relationship) between EO and new venture performance. However, our research finds that EO is a significant predictor of opportunity recognition and new venture performance in emerging economies.

Second, regarding new ventures in emerging markets, previous studies have neglected opportunity-seeking behaviors through EO. This in turn leads to poor policy implications and perhaps causes a higher failure ratio of new ventures in emerging markets. Therefore, our study provides insights for new ventures on the sensing, shaping and seizing of entrepreneurial opportunities in order to gain sustainable growth in emerging markets (Barreto 2010; Teece 2007).

Third, our research used empirical data of newly born ventures in an emerging economy and executed SmartPLS while using EO as a first and second-order construct (post hoc analysis). It advances the existing body of knowledge in two ways. First, most of the previous studies are limited to developed markets while emerging markets have been rarely touched. Second, using EO as first and second-order constructs in PLS takes us ahead of previous research studies where EO has been used as a first-order construct in a simple regression.

Fourth, previous studies have shown fragmented results on the relationship between EO and performance namely significant, insignificant, positive, or no relationship. This is because of some missing potential predictors in the apparent 
empirical disjunction. We found that opportunity recognition as a mediator increases EO impact on new venture performance. It advances our understanding of the relationship between EO and performance and favors the prediction of Lumpkin and Dess (1996) who claimed entrepreneurial actions and especially opportunity discovery could be a potential mechanism. Additionally, related to the emerging market context, our study shows the most influential dimensions of EO on opportunity recognition in emerging markets. These dimensions include innovativeness, risk-taking and proactiveness. They are considered less expensive and more convenient for SMEs in emerging markets. Therefore, rather than applying extra financial resources that are often expensive, our study shows that less risky and convenient resources such as the three dimensions of EO can be utilized by new ventures in emerging markets.

Fifth, the boundaries of the RBV had earlier been extended by considering entrepreneurial ability as a resource that helps ventures in the recognition of new opportunities to enhance performance (see Alvarez and Busenitz 2001). Thus, our study adds an empirical contribution to this model by showing that new ventures use EO as a resource to discover new opportunities and for performance gains particularly in the context of emerging markets.

\subsection{Implications for practitioners}

Regarding implications for practitioners, we observe that managers of new ventures in both emerging and developed markets should promote or employ entrepreneurial activities to exploit new opportunities as a means of sustaining performance. An enduring entrepreneurial culture can be a more viable growth strategy as compared to investment in other activities (Anwar and Shah 2020). This is even more important for new and small ventures in emerging economies with significant resource constraints (Cai et al. 2016).

\subsection{Limitations and further research}

We acknowledge a few limitations of our study. First, our model is based on the empirical evidence gathered from newly born ventures that are categorized as SMEs. Future studies may investigate other types of firms matured firms using the second-order construct of EO that we have applied in our study. This may provide useful insights for both practitioners and researchers.

Second, we reiterate that prior studies have shown a mediated relationship between dimensions underlying the EO construct and performance (e.g., Chryssochoidis et al. 2016; Kantur 2016). We also hypothesized on a partial mediation. Given this, we suggest that a study including a set of mediators would indicate the weight of these mediators and, thus, their role in explaining how EO influences performance. Future research may also examine the relationships between these mediators since a more complex relationship may be observed, e.g., a mediated or a moderated mediation. 
Third, although we obtained all items from the established literature, in our analysis risk-taking produced a good but weaker loading on the second-order construct than the other dimensions. As argued above, we assume that it may be due to the difference in the effects of risk-taking on SMEs in comparison to larger firms. This underlines the need for further factor analyses with different samples. Furthermore, the data was collected in an emerging market which may not be representative of all markets especially in advanced economies. We did not adduce any argument as to why this may differ in other settings. Therefore, our model should be tested not only between new and established ventures but also between emerging and developed economies, which would provide a more generalizable insight for the topic of EO.

Fourth, instead of working with each separate dimension of the EO construct, we decided to incorporate different dimensions and work with them as a single second-order construct. This was successful as our results showed that a second-order model worked as expected (external validity). Moreover, it shifts the focus from separate dimensions to a holistic view of EO. Nevertheless, we encourage researchers to elaborate on the completeness of this second-order construct. Are there more dimensions in this construct? Can it also be approached with formative sub-constructs? These questions will help researchers to investigate EO and the mechanisms of its influence on a firm's performance.

Fifth, apart from the differences in emerging and established market contexts, concepts such as risk-taking or proactiveness may strongly differ between countries (Henrich et al. 2010). ${ }^{1}$ In the event of international cooperation, interactions might be biased through value differences between individuals in teams (Kirkman and Shapiro 2005). Consequently, future research may perform similar analyses including countries of wide different cultural backgrounds. This may be lead to differences in $\mathrm{EO}$ and its relationship to opportunity recognition and venture performance.

\section{Conclusion}

Our research examined and tested predictions about the mediating role of opportunity recognition between EO and new venture performance in emerging markets. The study also examined the effect of opportunity recognition on venture performance. Even though we found empirical support for the derived hypotheses, this line of inquiry also opens an opportunity for theory building regarding which dimension of EO is more appropriate in opportunity recognition concerning newly born enterprises in emerging market settings.

\footnotetext{
1 Note that Hofstede's Uncertainty Avoidance dimension explicitly does not measure risk taking behavior (de Mooij 2013; Hofstede 2006).
} 


\section{Appendix}

Item number $\quad$ Constructs

\section{Entrepreneurial orientation}

\section{Innovativeness}

Item 1

Item 2

Item 3

\section{Risk taking}

Item 1

Item 2

Item 3

\section{Proactive behavior}

Item 1

Item 2

Item 3

Opportunity recognition

Item 1

Item 2

Item 3

Item 4

Item 5

\section{New venture performance}

Item 1

Item 2

Item 3

Item 4

Item 5

Item 6
In general, the top managers of my firm favor a strong emphasis on $\mathrm{R} \& \mathrm{D}$, tech. leadership, and innovations

My firm has marketed many new lines of products or services in the past 5 years

Changes in product or service lines have usually been quite dramatic

In general, the top managers have a strong proclivity for high-risk projects (with chances of very high returns)

In general, the top managers of my firm believe that owning to the nature of the environment, bold, wide-ranging acts are necessary to achieve the firm's objectives

When confronted with decision-making situations involving uncertainty, my firm typically adopts a bold, aggressive posture in order to maximize the probability of exploiting potential opportunities

In dealing with its competitors, my firm typically initiates actions, which competitors then respond to

In dealing with its competitors, my firm is very often the first business to introduce new products/services, administrative techniques, operating technologies, etc

In dealing with its competitors, my firm typically adopts a very competitive, undo-the- competitors posture

Searching and identifying opportunities from changes in customer demands and preferences

Searching and identifying opportunities from changes in economic environment

Searching and identifying opportunities from changes in political environment

Searching and identifying opportunities from changes in technological environment

Searching and identifying opportunities from changes in regulatory environment

Return on investment

Return on assets

Return on equity

Sale growth

Employees satisfaction

Employee loyalty 
Funding Open Access funding enabled and organized by Projekt DEAL.

Open Access This article is licensed under a Creative Commons Attribution 4.0 International License, which permits use, sharing, adaptation, distribution and reproduction in any medium or format, as long as you give appropriate credit to the original author(s) and the source, provide a link to the Creative Commons licence, and indicate if changes were made. The images or other third party material in this article are included in the article's Creative Commons licence, unless indicated otherwise in a credit line to the material. If material is not included in the article's Creative Commons licence and your intended use is not permitted by statutory regulation or exceeds the permitted use, you will need to obtain permission directly from the copyright holder. To view a copy of this licence, visit http://creativecommons.org/licen ses/by/4.0/.

\section{References}

Adomako S, Danso A, Boso N, Narteh B (2018) Entrepreneurial alertness and new venture performance: facilitating roles of networking capability. Int Small Bus J 36(5):453-472

Alam A, Uddin M, Yazdifar H (2019) Institutional determinants of R\&D investment: evidence from emerging markets. Technol Forecast Soc Change 138:34-44

Ali S, Li G, Yang P, Hussain K, Latif Y (2020) Unpacking the importance of intangible skills in new product development and sustainable business performance; strategies for marketing managers. PLoS ONE 15(9):e0238743

Alvarez SA, Busenitz LW (2001) The entrepreneurship of resource-based theory. J Manag 27(6):755-775

Alvarez SA, Barney JB, Newman AM (2015) The poverty problem and the industrialization solution. Asia Pacific J Manag 32(1):23-37

Amin M, Thurasamy R, Aldakhil AM, Kaswuri AHB (2016) The effect of market orientation as a mediating variable in the relationship between entrepreneurial orientation and SMEs performance. Nankai Bus Rev Int 7(1):39-59

Anwar M (2018) Business model innovation and SMEs performance-Does competitive advantage mediate? Int J Innov Manag 22(07): 1850057

Anwar M, Ali Shah SZ (2020) Managerial networking and business model innovation: empirical study of new ventures in an emerging economy. J Small Bus Entrep 32(3):265-286

Anwar M, Shah SZ (2020) Entrepreneurial orientation and generic competitive strategies for emerging SMEs: financial and nonfinancial performance perspective. J Public Affairs 21:e2125

Anwar M, Khan SZ, Khan NU (2018) Intellectual capital, entrepreneurial strategy and new ventures performance: mediating role of competitive advantage. Bus Econ Rev 10(1):63-93

Baron RM, Kenny DA (1986) The moderator-mediator variable distinction in social psychological research: conceptual, strategic, and statistical considerations. J Personal Soc Psychol 51(6):1173

Barreto I (2010) Dynamic capabilities: a review of past research and an agenda for the future. J Manag 36(1):256-280

Berry LL, Bolton RN, Bridges CH, Meyer J, Parasuraman A, Seiders K (2010) Opportunities for innovation in the delivery of interactive retail services. J Interact Mark 24(2):155-167

Brettel M, Chomik C, Flatten TC (2015) How organizational culture influences innovativeness, proactiveness, and risk-taking: fostering entrepreneurial orientation in SMEs. J Small Bus Manag 53(4):868-885

Bull I, Willard GE (1993) Towards a theory of entrepreneurship. J Bus Ventur 8(3):183-195

Cai L, Chen J, Peng X, Chen B (2016) The effect of symbiosis strategy on opportunity creation: case study of new ventures in China. Int J Technol Manag 72(1-3):171-191

Cardon MS, Gregoire DA, Stevens CE, Patel PC (2013) Measuring entrepreneurial passion: conceptual foundations and scale validation. J Bus Ventur 28(3):373-396

Carrión GC, Henseler J, Ringle CM, Roldán JL (2016) Prediction-oriented modeling in business research by means of PLS path modeling: Introduction to a JBR special section. J Bus Res 69(10):4545-4551

Cassia L, Minola T (2012) Hyper-growth of SMEs: toward a reconciliation of entrepreneurial orientation and strategic resources. Int J Entrep Behav Res 18(2):179-197 
Chari MD, Banalieva ER (2015) How do pro-market reforms impact firm profitability? The case of India under reform. J World Bus 50(2):357-367

Chen MH, Yang YJ (2009) Typology and performance of new ventures in Taiwan: a model based on opportunity recognition and entrepreneurial creativity. Int J Entrep Behav Res 15(5):398-414

Chen PC, Chan WC, Hung SW, Lin DZ (2020) How entrepreneurs recognise entrepreneurial opportunity and its gaps: a cognitive theory perspective. Technol Anal Strateg Manag 32(2):223-238

Chryssochoidis G, Dousios D, Tzokas N (2016) Small firm adaptive capability, competitive strategy, and performance outcomes: competing mediation vs. moderation perspectives. Strateg Change 25(4):441-466

Cooper RG (2000) New product performance: what distinguishes the star products. Aust J Manag 25(1):17-45

Covin JG, Slevin DP (1989) Strategic management of small firms in hostile and benign environments. Strateg Manag J 10(1):75-87

Covin JG, Wales WJ (2012) The measurement of entrepreneurial orientation. Entrep Theory Pract 36(4):677-702

Czakon W, Niemand T, Gast J, Kraus S, Frühstück L (2020) Designing coopetition for radical innovation: an experimental study of managers' preferences for developing self-driving electric cars. Technol Forecast Soc Change 155:119992

Dali N, Harbi S (2016) The effect of risk perception and cognitive biases on the evaluation of opportunity in family and non-family entrepreneurs: the case of Tunisian entrepreneurs. J Enterp Cult 24(03):281-312

Danso A, Adomako S, Damoah JO, Uddin M (2016) Risk-taking propensity, managerial network ties and firm performance in an emerging economy. J Entrep 25(2):155-183

Davidsson P (2015) Entrepreneurial opportunities and the entrepreneurship nexus: a re-conceptualization. J Bus Ventur 30(5):674-695

Day GS (2011) Closing the marketing capabilities gap. J Mark 75(4):183-195

Day GS (2014) An outside-in approach to resource-based theories. J Acad Mark Sci 42(1):27-28

De Carolis DM, Saparito P (2006) Social capital, cognition, and entrepreneurial opportunities: a theoretical framework. Entrep Theory Pract 30(1):41-56

de Mooij M (2013) On the misuse and misinterpretation of dimensions of national culture. Int Mark Rev 30(3):253-261

Dencker JC, Gruber M (2015) The effects of opportunities and founder experience on new firm performance. Strateg Manag J 36(7):1035-1052

Devece C, Ribeiro-Soriano DE, Palacios-Marqués D (2019) Coopetition as the new trend in inter-firm alliances: literature review and research patterns. Rev Manag Sci 13(2):207-226

Donbesuur F, Boso N, Hultman M (2020) The effect of entrepreneurial orientation on new venture performance: contingency roles of entrepreneurial actions. J Bus Res 118:150-161

Fatima ST (2017) Globalization and technology adoption: evidence from emerging economies. J Int Trade Econ Dev 26(6):724-758

Ferris SP, Javakhadze D, Rajkovic T (2017) CEO social capital, risk-taking and corporate policies. J Corp Finance 47:46-71

Filser M, Eggers F, Kraus S, Málovics É (2014) The effect of financial resource availability on entrepreneurial orientation, customer orientation and firm performance in an international context: an empirical analysis from Austria and Hungary. J East Eur Manag Stud 19(1):7-30

Filser M, Tiberius V, Kraus S, Zeitlhofer T, Kailer N, Müller A (2020) Opportunity recognition: conversational foundations and pathways ahead. Entrep Res J 1:1-30

Fornell C, Larcker DF (1981) Evaluating structural equation models with unobservable variables and measurement error. J Mark Res 18(1):39-50

Fornell C, Bookstein FL (1982) Two structural equation models: LISREL and PLS applied to consumer exitvoice theory. J Market Res 19(4):440-452

Franke G, Sarstedt M (2019) Heuristics versus statistics in discriminant validity testing: a comparison of four procedures. Int Res 29(3):430-447

Galbraith JR (1973) Designing complex organizations. Addison-Wesley Longman Publishing Co., Inc., Boston

Gao Y, Ge B, Lang X, Xu X (2018) Impacts of proactive orientation and entrepreneurial strategy on entrepreneurial performance: an empirical research. Technol Forecast Soc Change 135:178-187

George D (2011) SPSS for windows step by step: a simple study guide and reference, 17.0 update, 10/e. Pearson Education India, Chennai 
George NM, Parida V, Lahti T, Wincent J (2016) A systematic literature review of entrepreneurial opportunity recognition: insights on influencing factors. Int Entrep Manag J 12(2):309-350

Geroski PA (1990) Innovation, technological opportunity, and market structure. Oxf Econ Pap 42(3):586-602

Ghosh BC, Liang TW, Meng TT, Chan B (2001) The key success factors, distinctive capabilities, and strategic thrusts of top SMEs in Singapore. J Bus Res 51(3):209-221

Gielnik MM, Zacher H, Frese M (2012) Focus on opportunities as a mediator of the relationship between business owners' age and venture growth. J Bus Ventur 27(1):127-142

Guo H, Su Z, Ahlstrom D (2016) Business model innovation: The effects of exploratory orientation, opportunity recognition, and entrepreneurial bricolage in an emerging economy. Asia Pac J Manag 33(2):533-549

Guo H, Tang J, Su Z, Katz JA (2017) Opportunity recognition and SME performance: the mediating effect of business model innovation. R\&D Manag 47(3):431-442

Guo R, Cai L, Fei Y (2019a) Knowledge integration methods, product innovation and high-tech new venture performance in China. Technol Anal Strateg Manag 31(3):306-318

Guo Z, Zhang J, Liu H (2019b) Opportunity recognition efficiency of small Chinese firms: findings from data envelopment analysis. Chin Manag Stud 13(4):760-777

Gupta VK, Niranjan S, Markin E (2020) Entrepreneurial orientation and firm performance: the mediating role of generative and acquisitive learning through customer relationships. Rev Manag Sci 14:1123-1147

Hair JF, Black WF, Babin BJ, Anderson RE (2010) Multivariate data analysis, 7th edn. Prentice-Hall, Upper Saddle River

Hair JF, Ringle CM, Sarstedt M (2011) PLS-SEM: indeed a silver bullet. J Mark Theory Pract 19(2):139-152

Hair JF Jr, Sarstedt M, Hopkins L, Kuppelwieser VG (2014) Partial least squares structural equation modeling (PLS-SEM). Eur Bus Rev 26:106-121

Hamel G (2012) What matters now: How to win in a world of relentless change, ferocious competition, and unstoppable innovation? Jossey-Bass, San Francisco

Hansen DJ, Shrader R, Monllor J (2011) Defragmenting definitions of entrepreneurial opportunity. J Small Bus Manag 49(2):283-304

Harms R, Schulz A, Kraus S, Fink M (2009) The conceptualisation of 'opportunity' in strategic management research. Int J Entrep Ventur 1(1):57-71

Helm R, Mauroner O, Dowling M (2010) Innovation as mediator between entrepreneurial orientation and spinoff venture performance. Int J Entrep Small Bus 11(4):472-491

Henrich J, Heine SJ, Norenzayan A (2010) The weirdest people in the world? Behav Brain Sci $33(2-3): 61-83$

Hofstede G (2006) What did GLOBE really measure? Researchers' minds versus respondents' minds. J Int Bus Stud 37(6):882-896

Hughes M, Eggers F, Kraus S, Hughes P (2015) The relevance of slack resource availability and networking effectiveness for entrepreneurial orientation. Int J Entrep Small Bus 26(1):116-138

Hulbert B, Gilmore A, Carson D (2015) Opportunity recognition by growing SMEs: A managerial or entrepreneurial function? J Strateg Mark 23(7):616-642

Hult GTM, Hurley RF, Knight GA (2004) Innovativeness: its antecedents and impact on business performance. Ind Mark Manag 33:429-438

Hyder S, Lussier RN (2016) Why businesses succeed or fail: a study on small businesses in Pakistan. J Entrep Emerg Econ 8(1):82-100

Ireland RD, Hitt MA, Sirmon DG (2003) A model of strategic entrepreneurship: the construct and its dimensions. J Manag 29(6):963-989

Jalali A, Jaafar M, Ramayah T (2014) Entrepreneurial orientation and performance: the interaction effect of customer capital. World J Entrep Manag Sustain Dev 10(1):48-68

Jiang N, Li L, Che M (2017) Entrepreneurial orientation and firm performance: the mediating and moderating effects. In: Atinc G (ed) Academy of management proceedings, vol. 2017, no. 1. Academy of Management, Briarcliff Manor, p 13583

Jin L, Madison K, Kraiczy ND, Kellermanns FW, Crook TR, Xi J (2017) Entrepreneurial team composition characteristics and new venture performance: a meta-analysis. Entrep Theory Pract 41(5):743-771

Jin J, Guo M, Zhang Z (2019) Selective adoption of open innovation for new product development in high-tech SMEs in emerging economies. IEEE Trans Eng Manag 48(1):171-177

Kallmuenzer A, Strobl A, Peters M (2018) Tweaking the entrepreneurial orientation-performance relationship in family firms: the effect of control mechanisms and family-related goals. Rev Manag Sci 12(4):855-883 
Kantur D (2016) Strategic entrepreneurship: mediating the entrepreneurial orientation-performance link. Manag Decis 54(1):24-43

Ketchen DJ, Ireland RD, Snow CC (2007) Strategic entrepreneurship, collaborative innovation, and wealth creation. Strateg Entrep J 1(3-4):371-385

Khodaei H, Scholten V, Wubben EF, Omta O (2016) Entrepreneurial orientation and opportunity recognition: the mediating role of absorptive capacity. In: Atinc G (ed) Academy of management proceedings, vol. 2016, no. 1. Academy of Management, Briarcliff Manor, p 17472

Kirkman BL, Shapiro DL (2005) The impact of cultural value diversity on multicultural team performance. In: Shapiro DL, von Glinow MA, Cheng JLC (eds) Advances in international management, vol 18. Managing multinational teams: Global perspectives. Elsevier, Amsterdam, pp 33-67

Kirzner IM (1985) Discovery and the capitalist process. University of Chicago Press, Chicago

Kozlenkova IV, Samaha SA, Palmatier RW (2014) Resource-based theory in marketing. J Acad Mark Sci 42(1):1-21

Kraus S, Rigtering JC, Hughes M, Hosman V (2012) Entrepreneurial orientation and the business performance of SMEs: a quantitative study from the Netherlands. Rev Manag Sci 6(2):161-182

Lechner C, Gudmundsson SV (2014) Entrepreneurial orientation, firm strategy and small firm performance. Int Small Bus J 32(1):36-60

Lin Y, Wu LY (2014) Exploring the role of dynamic capabilities in firm performance under the resource-based view framework. J Bus Res 67(3):407-413

Lindell MK, Whitney DJ (2001) Accounting for common method variance in cross-sectional research designs. J Appl Psychol 86(1):114

Lowry PB, Gaskin J (2014) Partial least squares (PLS) structural equation modeling (SEM) for building and testing behavioral causal theory: When to choose it and how to use it. IEEE Trans Prof Commun 57(2):123-146

Lumpkin GT, Dess GG (1996) Clarifying the entrepreneurial orientation construct and linking it to performance. Acad Manag Rev 21(1):135-172

Lumpkin GT, Dess GG (2001) Linking two dimensions of entrepreneurial orientation to firm performance: the moderating role of environment and industry life cycle. J Bus Ventur 16(5):429-451

Lumpkin GT, Lichtenstein BB (2005) The role of organizational learning in the opportunity-recognition process. Entrep Theory Pract 29(4):451-472

Ma C, Gu J, Liu H (2017) Entrepreneurs' passion and new venture performance in China. Int Entrep Manag J 13(4):1043-1068

Maine E, Soh PH, Dos Santos N (2015) The role of entrepreneurial decision-making in opportunity creation and recognition. Technovation 39:53-72

March JG, Simon H (1968) Organizations. Wiley, New York

Marom S, Lussier RN, Sonfield M (2019) Entrepreneurial strategy: the relationship between firm size and levels of innovation and risk in small businesses. J Small Bus Strategy 29(3):33-45

Miller D, Friesen PH (1978) Archetypes of strategy formulation. Manag Sci 24(9):921-933

Miocevic D, Morgan RE (2018) Operational capabilities and entrepreneurial opportunities in emerging market firms: explaining exporting SME growth. Int Mark Rev 35(2):320-341

Nambisan S, Zahra SA (2016) The role of demand-side narratives in opportunity formation and enactment. J Bus Ventur Insights 5:70-75

Nieto M, Quevedo P (2005) Absorptive capacity, technological opportunity, knowledge spillovers, and innovative effort. Technovation 25(10):1141-1157

Ojiako U, Chipulu M, Karatas-Ozkan M, Siao MJ, Maguire S (2015) Intelligence management opportunities for SMEs. J Small Bus Enterp Dev 22(4):698-715

Parida V, Lahti T, Wincent J (2016) Exploration and exploitation and firm performance variability: a study of ambidexterity in entrepreneurial firms. Int Entrep Manag J 12(4):1147-1164

Parnell JA, Long Z, Lester D (2015) Competitive strategy, capabilities and uncertainty in small and medium sized enterprises (SMEs) in China and the United States. Manag Decis 53(2):402-431

Patel PC, Kohtamäki M, Parida V, Wincent J (2015) Entrepreneurial orientation-as-experimentation and firm performance: The enabling role of absorptive capacity. Strateg Manag J 36(11):1739-1749

Podsakoff PM, Organ DW (1986) Self-reports in organizational research: problems and prospects. J Manag 12(4):531-544

Prashantham S, Kumar K, Bhattacharyya S (2019) International new ventures from emerging economies: network connectivity and legitimacy building. Manag Organ Rev 15(3):615-641

Rauch A, Wiklund J, Lumpkin GT, Frese M (2009) Entrepreneurial orientation and business performance: an assessment of past research and suggestions for the future. Entrep Theory Pract 33(3):761-787 
Renko M, Shrader RC, Simon M (2012) Perception of entrepreneurial opportunity: a general framework. Manag Decis 50(7):1233-1251

Rhee J, Park T, Lee DH (2010) Drivers of innovativeness and performance for innovative SMEs in South Korea: mediation of learning orientation. Technovation 30(1):65-75

Ringle CM, Sarstedt M, Straub DW (2012) Editor's comments: A critical look at the use of PLS-SEM in MIS quarterly. MIS Q 36(1):3-14

Ringle CM, Wende S, Becker JM (2015) SmartPLS 3. SmartPLS GmbH, Boenningstedt. J Serv Sci Manag, 10(3)

Runyan R, Droge C, Swinney J (2008) Entrepreneurial orientation versus small business orientation: What are their relationships to firm performance? J Small Bus Manag 46(4):567-588

Sambasivan M, Abdul M, Yusop Y (2009) Impact of personal qualities and management skills of entrepreneurs on venture performance in Malaysia: opportunity recognition skills as a mediating factor. Technovation 29(11):798-805

Schneider P (2018) Managerial challenges of Industry 4.0: an empirically backed research agenda for a nascent field. Rev Manag Sci 12(3):803-848

Shane S, Venkataraman S (2000) The promise of entrepreneurship as a field of research. Acad Manag Rev 25(1):217-226

Shirokova G, Bogatyreva K, Beliaeva T, Puffer S (2016) Entrepreneurial orientation and firm performance in different environmental settings: contingency and configurational approaches. J Small Bus Enterp Dev 23(3):703-727

Shrader RC, Hills GE (2015) Opportunity recognition: perceptions of highly successful entrpreneurs. J Small Bus Strategy 14(2):92-108

Singh SK, Gaur SS (2018) Entrepreneurship and innovation management in emerging economies. Manag Decis 56(1):2-5

Soekotjo H, Cahyono K, Nugroho N, Rismawati R, Kawiana I (2001) The role of mediation of product innovation in improving enterprises orientation of marketing performance of tofu industry. Manag Sci Lett 11(2):473-480

Stevenson HH, Gumpert DE (1985) The heart of entrepreneurship. Harv Bus 63(2):85-94

Stevenson HH, Jarillo JC (1990) A paradigm of entrepreneurship management. Strateg Manag J 11(1):17-27

Story VM, Boso N, Cadogan JW (2015) The form of relationship between firm-level product innovativeness and new product performance in developed and emerging markets. J Prod Innov Manag 32(1):45-64

Su Z, Xie E, Li Y (2011) Entrepreneurial orientation and firm performance in new ventures and established firms. J Small Bus Manag 49(4):558-577

Tang J, Kacmar KMM, Busenitz L (2012) Entrepreneurial alertness in the pursuit of new opportunities. J Bus Ventur 27(1):77-94

Teece DJ (2007) Explicating dynamic capabilities: the nature and microfoundations of (sustainable) enterprise performance. Strateg Manag J 28(13):1319-1350

Urban B, Wood E (2015) The importance of opportunity recognition behaviour and motivators of employees when engaged in corporate entrepreneurship. J Bus Econ Manag 16(5):980-994

Vogel P (2017) From venture idea to venture opportunity. Entrep Theory Pract 41(6):943-971

Wales WJ, Kraus S, Filser M, Stöckmann C, Covin JG (2020) The status quo of research on entrepreneurial orientation: conversational landmarks and theoretical scaffolding. J Bus Res. https://doi.org/10.1016/j. jbusres.2020.10.046

Wang D, Chen YG (2010) The effect of entrepreneurial social capital on new venture performance. Sci Manag Res 30(2):25-29

Wang YL, Ellinger AD, Jim Wu YC (2013) Entrepreneurial opportunity recognition: an empirical study of R\&D personnel. Manag Decis 51(2):248-266

Wang T, Thornhill S, De Castro JO (2017) Entrepreneurial orientation, legitimation, and new venture performance. Strateg Entrep J 11(4):373-392

Wang X, Dass M, Arnett DB, Yu X (2020) Understanding firms' relative strategic emphases: an entrepreneurial orientation explanation. Ind Mark Manag 84:151-164

Wasdani KP, Mathew M (2014) Potential for opportunity recognition: differentiating entrepreneurs. Int J Entrep Small Bus 23(3):336-362

Wiklund J (1999) The sustainability of the entrepreneurial orientation-performance relationship. Entrep Theory Pract 24(1):37-48

Wiklund J, Shepherd D (2005) Entrepreneurial orientation and small business performance: a configurational approach. J Bus Ventur 20:71-91 
Williams LJ, Hartman N, Cavazotte F (2010) Method variance and marker variables: a review and comprehensive CFA marker technique. Organ Res Methods 13(3):477-514

Wright RW, Etemad H (2001) SMEs and the global economy. J Int Manag 7(3):151-154

Wu L, Xu L (2020) The role of venture capital in SME loans in China. Res Int Bus Finance 51:101081

Yang W, Meyer KE (2019) Alliance proactiveness and firm performance in an emerging economy. Ind Mark Manag 82:226-237

Yitshaki R, Kropp F (2016) Entrepreneurial passions and identities in different contexts: a comparison between high-tech and social entrepreneurs. Entrep Reg Dev 28(3-4):206-233

Yu X, Li Y, Su Z, Tao Y, Nguyen B, Xia F (2020) Entrepreneurial bricolage and its effects on new venture growth and adaptiveness in an emerging economy. Asia Pac J Manag 37:1141-1163

Yuliansyah Y, Rammal HG, Rose E (2016) Business strategy and performance in Indonesia's service sector. J Asia Bus Stud 10(2):164-182

Zahra SA, Garvis DM (2000) International corporate entrepreneurship and firm performance: the moderating effect of international environmental hostility. J Bus Ventur 15(5):469-492

Zahra S, Hayton J, Marcel J, O’Neill H (2001) Fostering entrepreneurship during international expansion: managing key challenges. Eur Manag J 19(4):359-369

Zehir C, Can E, Karaboga T (2015) Linking entrepreneurial orientation to firm performance: the role of differentiation strategy and innovation performance. Procedia Soc Behav Sci 210:358-367

Zhao Y, Li Y, Lee SH, Chen LB (2011) Entrepreneurial orientation, organizational learning, and performance: evidence from China. Entrep Theory Pract 35(2):293-317

Zhou KZ, Li CB (2010) How strategic orientations influence the building of dynamic capability in emerging economies. J Bus Res 63(3):224-231

Publisher's Note Springer Nature remains neutral with regard to jurisdictional claims in published maps and institutional affiliations. 